\title{
Histone H1 Gene
}

National Cancer Institute

\section{Source}

National Cancer Institute. Histone H1 Gene. NCI Thesaurus. Code C154267.

A gene encoding the linker histone protein histone $\mathrm{H} 1$. 